\title{
Karkearehujen sulavuuden määritys tarkentunut
}

\author{
Marketta Rinne $^{1)}$, Pekka Huhtanen ${ }^{1,2)}$ ja Juha Nousiainen ${ }^{3)}$ \\ ${ }^{1)}$ MTT, Kotieläintuotannon tutkimus, 31600 Jokioinen, etunimi.sukunimi@mtt.fi \\ ${ }^{2)}$ Cornell University, Department of Animal Science, 269 Morrison Hall, Ithaca, NY 14853-4801, USA \\ ${ }^{3)}$ Valio Oy, Alkutuotanto, PL 10, 00039 Valio,etunimi.sukunimi@valio.fi
}

\section{Tiivistelmä}

Karkearehujen sulavuus vaikuttaa merkittävästi rehujen energia- ja valkuaisarvoihin, syöntipotentiaaliin ja rehua syövien lehmien maidontuotantoon. Sulavuuden luotettava määrittäminen on siis erittäin tärkeää rehujen tuotantovaikutuksen määrittämiseksi ja ruokinnan taloudellisen optimoinnin lähtötietona. Tässä kirjoituksessa käsitellään märehtijöiden ruokinnassa käytettävien karkearehujen sulavuuden määrittämistä.

Karkearehujen sulavuuden referenssimenetelmänä käytetään lampailla in vivo ruokinnan ylläpitotasolla suoritettua sulavuuskoetta, jossa sulavuus lasketaan eläinten syömän ja sonnassa erittyneen ravintoaineen määrän erotuksena. Rehujen sulavuutta voidaan arvioida erilaisin laboratorioanalyysein, jotka jäljittelevät eläinten ruoansulatuskanavassa tapahtuvaa rehun sulatusta. Tässä tutkimusaineistossa on mukana 86 säilörehua noin 10 vuoden ajalta, joiden sulavuus on määritetty lampailla in vivo ja monipuolisesti laboratoriomenetelmin. Karkearehutyypeistä mukana ovat nurmisäilörehu ensimmäisestä sadosta ja jälkisadosta, puna-apila- ja kokoviljasäilörehu.

Yksittäisten kemiallisten komponenttien (RV, NDF, ADF, ligniini) yhteydet sulavuuteen eivät ole riittäviä sulavuuden ennustamiseen. Biologiset laboratoriomenetelmät orgaanisen aineen pepsiinisellulaasiliukoisuus (OMS) ja sulamattoman kuidun pitoisuus (iNDF) sen sijaan ennustivat karkearehujen orgaanisen aineen sulavuuden riittävän tarkasti käytännön ruokinnansuunnittelua varten. Ennusteiden tarkkuus parani merkittävästi, kun analyysitulokset muunnettiin sulavuudeksi rehutyyppikohtaisia korjausyhtälöitä käyttäen eli erikseen ensimmäisestä sadosta ja jälkikasvusta tehdyille nurmisäilörehuille, palkokasvisäilörehuille ja kokoviljasäilörehuille. Rehutyyppikohtaiset korjausyhtälöt ovat tilasäilörehujen D-arvon määrityksen taustalla Artturi-analyysissä. Tässä kirjoituksessa esitettyihin yhtälöihin perustuen on myös laadittu MS Excel -pohjainen tiedosto, joka on käytettävissä Artturißverkkopalvelussa (www.mtt.fi/artturi).

Kuidun (NDF) ja sulamattoman kuidun (iNDF) määrityksen kautta rehun orgaaninen aine saadaan jaettua kolmeen biologisesti mielekkääseen osaan: NDS (orgaaninen aine - kuitu), potentiaalisesti sulava kuitu (NDF - iNDF) ja iNDF. Solunsisällysaineiden todellinen sulavuus on lähes täydellinen ja sen vaihtelu on hyvin pientä. Kuidun sulavuus sen sijaan on selvästi vähäisempää ja vaihtelevampaa, eli rehujen sulavuuden määrityksessä oleellista on nimenomaan kuidun pitoisuuden ja sulavuuden selvittäminen. Rehutyyppikohtaiset summatiiviset mallit ennustivat karkearehujen D-arvon lähes yhtä hyvin kuin OMS ja iNDF. Kun koko aineistoa tarkasteltiin yhdessä, summatiiviset mallit olivat parempia kuin iNDF ja erityisesti OMS.

Tutkimuksen tuloksena käytännön tilarehujen analytiikka on merkittävästi tarkentunut, kun NIRS-kalibroinnin referenssimenetelmän luotettavuutta on pystytty parantamaan. Aikaisempi ensimmäisen sadon D-arvon aliarvostus ja jälkisadon yliarvostus on saatu poistettua. Analyysin tarkkuudessa ollaan lähestymässä lampailla tehtävien sulavuuskokeiden keskimääräistä satunnaisvirhettä, joka on teoreettinen minimivirhe, johon rehujen sulavuusmittauksissa voidaan päästä.

Asiasanat: D-arvo, laboratoriomenetelmä, nurmirehu, rehuanalyysi, rehuarvo, sulamaton kuitu, sulavuus, säilörehu 


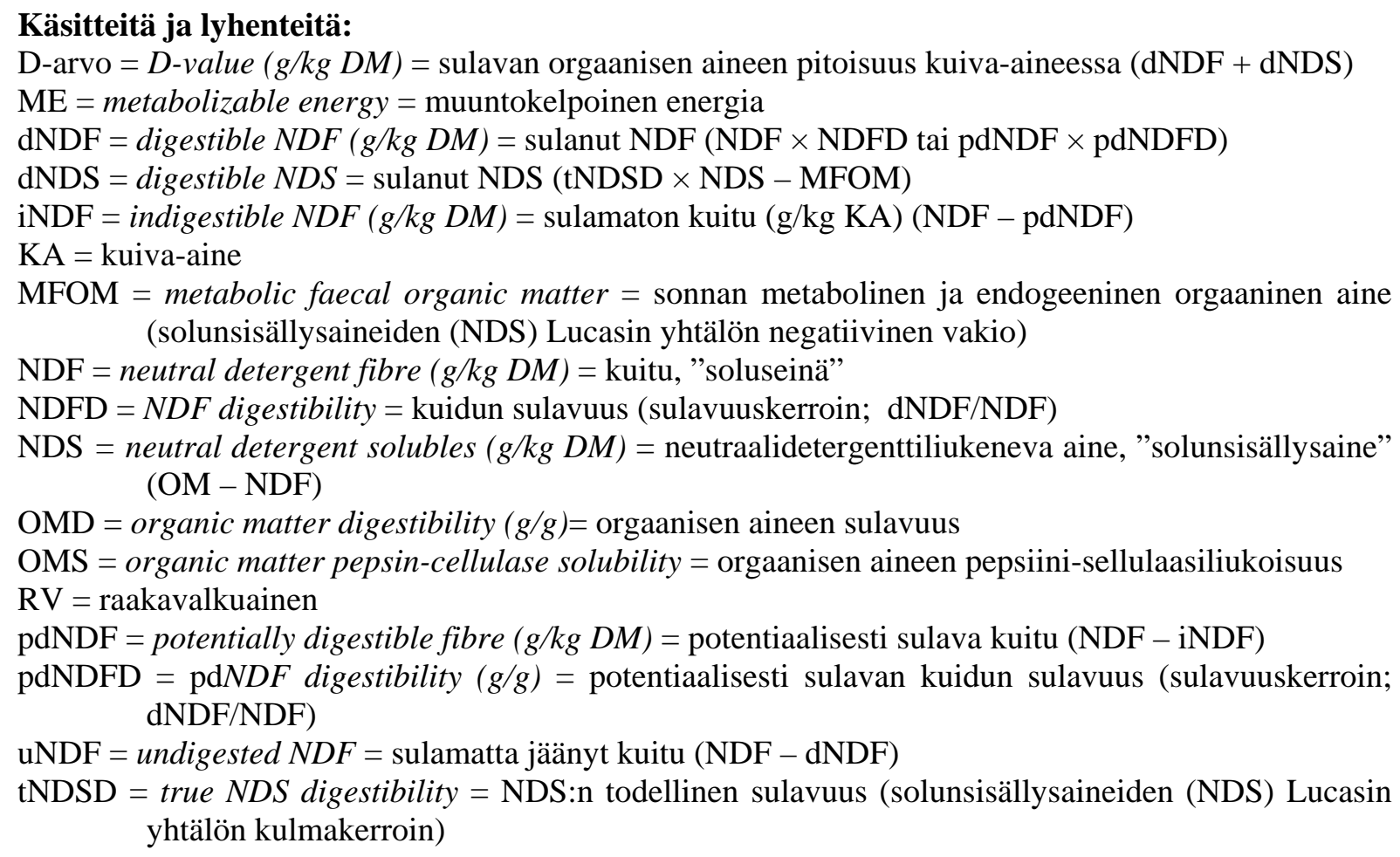

\section{Johdanto}

Karkearehujen sulavuus vaikuttaa merkittävästi rehujen energia- ja valkuaisarvoihin (MTT 2006), syöntipotentiaaliin (Huhtanen ym. 2007, Rinne ym. 2008) ja rehua syövien lehmien maidontuotantoon (Rinne 2000, Rinne \& Huhtanen 2006, Huhtanen \& Rinne 2007). Sulavuuden luotettava määrittäminen on siis erittäin tärkeää rehujen tuotantovaikutuksen määrittämiseksi ja ruokinnan taloudellisen optimoinnin lähtötietona (Huhtanen ym. 2008). Tässä kirjoituksessa käsitellään märehtijöiden ruokinnassa käytettävien karkearehujen sulavuuden määrittämistä. Kirjoitus perustuu prof. emeritus Esko Poutiaiselle omistetussa Agricultural and Food Science -lehden numerossa julkaistuun Huhtasen ym. (2006) artikkeliin.

Nurmirehujen sulavuus vaihtelee huomattavasti johtuen lähinnä kasvilajista ja kasvien kehitysvaiheesta korjuuhetkellä (Rinne 2000). Myös säilönnän aikana sulavuus laskee, mutta jos säilöntä onnistuu normaalisti, on sulavuuden lasku alle 2 \%-yksikköä (Huhtanen ym. 2005). Karkearehujen sulavuuden vaihtelu on huomattavasti suurempaa kuin väkirehukomponenttien. Yksittäinen karkearehu muodostaa usein yli puolet märehtijän koko rehuannoksen kuiva-aineesta, kun taas väkirehukomponentteja on tyypillisesti useita, joten yksittäisten väkirehukomponenttien osuudet ruokinnassa ovat huomattavasti pienempiä ja myös niiden koostumus ja sulavuus vaihtelevat vähemmän. Karkearehujen sulavuuden määrittämisellä on siis huomattavasti suurempi merkitys kuin väkirehujen, joiden osalta ruokinnan suunnittelussa voidaan pääsääntöisesti käyttää Rehutaulukoissa (MTT 2006) esitettyjä keskimääräisiä arvoja.

Märehtijöiden karkearehujen energia-arvon määritys Suomessa perustuu D-arvoon eli sulavan orgaanisen aineen $(\mathrm{OM})$ pitoisuuteen rehun kuiva-aineessa. D-arvon laskemiseksi pitää tuntea rehun orgaanisen aineen sulavuus [OMD (laatu g/g OM, mutta sulavuuskertoimet ilmoitetaan ilman laatua)] ja pitoisuus [1000 - tuhkapitoisuus (g/kg KA)]. D-arvo (g/kg KA) lasketaan siis seuraavasti: OMD $\times$ OM-pitoisuus (g/kg KA). Säilörehun muuntokelpoisen energian (ME) pitoisuus (MJ) lasketaan MAFF:in (1984) mukaan olettaen että yksi kg sulavaa orgaanista ainetta sisältää 16 MJ ME. Säilörehun ME-arvo on siis: D-arvo (g/kg KA) × 0.016. Rehuyksikköarvo lasketaan ME-arvosta jakamalla se vakiolla 11.7. Ei-tieteellisissä yhteyksissä D-arvo ilmaistaan usein prosentteina, jolloin ME-kerroin on 0.16 .

Karkearehujen sulavuuden referenssimenetelmänä käytetään lampailla in vivo ruokinnan ylläpitotasolla suoritettua sulavuuskoetta, jossa sulavuus lasketaan eläinten syömän ja sonnassa erittyneen ravintoaineen määrän erotuksena [ks. menetelmäkuvaus Stefanskan ym. (2008) kirjoituksesta]. Vaikka 
lampailla ylläpitotasolla määritetty karkearehun sulavuus on huomattavasti korkeampi kuin lypsylehmillä käytännön ruokintatilanteissa, muodostavat lampailla määritetyt sulavuudet rehuarvojen perustan. Lampaiden avulla rehujen suhteelliset erot voidaan arvioida varsin luotettavasti. Ruokintatason ja rehuannoksen koostumuksen vaikutukset rehun energia-arvoon otetaan huomioon korjausyhtälön avulla siten, että lehmien laskennallinen energian saanti vastaa todellista.

Sulavuuskokeita eläimillä in vivo ei voida tehdä rutiininomaisesti. Rehujen sulavuutta voidaan arvioida erilaisin laboratorioanalyysein, jotka jäljittelevät eläinten ruoansulatuskanavassa tapahtuvaa rehun sulatusta laboratorio-olosuhteissa in vitro tai joiden yhteys in vivo -sulavuuteen on hyvä. In vitro -menetelmissä voidaan rehun sulatukseen koeputkessa käyttää pöstinestettä [Tilleyn ja Terryn (1963) menetelmä muunnoksineen] tai kaupallisesti saatavilla olevia sellulaasientsyymivalmisteita. Orgaanisen aineen pepsiini-sellulaasiliukoisuuteen (OMS) perustuva menetelmä (Nousiainen ym. 2003) on Suomessa käytössä MTT:ssä, Valio Oy:ssä ja Helsingin yliopistossa.

In vitro -menetelmät poikkeavat monissa suhteissa in vivo -sulavuudesta. In vivo -sulavuus on näennäinen sulavuus. Sonnassa erittyy metabolista ja endogeenistä ainesta (MFOM), joka koostuu ruoansulatuskanavasta erittyneesta aineksesta seka sulamattomasta pötsissä ja paksusuolessa muodostuneesta mikrobimassasta, jotka itse asiassa ovat sulaneesta rehusta muodostuneita, vaikka erittyvätkin sontaan. Todellisen sulavuuden laskemiseksi MFOM pitäisi pystyä erottamaan sonnasta. Metabolista ja endogeenistä ainetta ei mm. OMS-mentelmässä muodostu, joten sellulaasiliukoisuus kuvaa todellista sulavuutta. Pötsinesteen käyttöön perustuvien in vitro -mentelmien tuloksiin sisältyy mikrobimassaa, jolloin hävikki ei kuvaa todellista sulavuutta. In vitro -menetelmät eivät ole yhtä tehokkaista kuidun sulattajia kuin mikrobit pötsiolosuhteissa (Nousiainen 2004, Rinne ym. 2006).

Laboratoriossa määritetty sulavuus täytyy suhteuttaa in vivo -sulavuuteen. Kun käytettävissä on riittävän laaja aineisto näytteitä joista on määritetty myös in vivo -sulavuus, voidaan arvioida kuinka hyvin kyseinen menetelmä pystyy ennustamaan sulavuuden eläimillä. Laboratorioarvojen (X-akseli) ja in vivo määritettyjen arvojen (Y-akseli) välille voidaan laskea regressioyhtälö, jota voidaan jatkossa käyttää laboratoriotuloksen muuntamiseksi vastaamaan in vivo -sulavuutta.Tässä kirjoituksessa tarkastellaan karkearehujen sulavuuden ennustamista eri menetelmillä käyttäen aineistona suomalaista systemaattisesti kerättyä säilörehuaineistoa. Tutkimushankkeen perimmäisenä tavoitteena on ollut kehittää käytännön rehuanalytiikan perustaksi luotettavia ja eläinkokeilla validoituja referenssimenetelmiä lähi-infrapunatekniikkaa (NIRS) varten (Huhtanen ym. 2006, Nousiainen 2004).

\section{Aineisto ja menetelmät}

Aineistossa on mukana 86 säilörehua noin 10 vuoden ajalta, joiden sulavuus on määritetty in vivo (taulukko 1). Näytteet on lisäksi analysoitu monipuolisesti laboratoriomenetelmin ja in situ eli uitettu pötsissä nailonpussimenetelmää käyttäen. Karkearehulajeista mukana ovat nurmisäilörehu ensimmäisestä sadosta ja jälkisadosta (2. ja 3. sato), puna-apila- ja kokoviljasäilörehu (raaka-aineina ohra ja vehnä). Suurin osa rehuista ja sulavuuskokeista on tehty MTT:ssä Jokioisilla, mutta aineistossa on mukana myös MTT:n Vihdin toimipaikassa (n=3) ja HY:ssä (Viikki n=6, Suitia n=6) tehtyjä rehuja.

Sulavuuskokeet pässeillä tehtiin ylläpitoruokintatasolla käyttäen sonnan kokonaiskeruumenetelmää. Rehu- ja sontanäytteet analysoitiin standardimenetelmin. OMS määritettiin Nousiaisen (2003) mukaan. Rehujen iNDF-pitoisuus määritettiin inkuboimalla rehunäytteitä (4 g) pienisilmäisissä nailonpusseissa (huokoskoko 6 tai $17 \mu \mathrm{m}$ ) karkearehuvaltaisella ruokinnalla olevien lehmien pötsissä 12 vuorokauden ajan. Inkubaation jälkeen pussit keitettiin NDF-liuoksessa ja tuhkattiin, jolloin iNDF voitiin esittää tuhkattomana.

In vivo -sulavuuden ja muiden menetelmien välistä yhteyttä tarkasteltiin yksikertaisella regressioanalyysillä (SAS proc REG) ja sekamalli-regressioanalyysillä (SAS Mixed), jossa satunnaistekijänä oli sulavuuskoe. Mallien vertailussa käytettiin mallin jäännösvaihtelua (residual mean squared error, RMSE) ja selitysastetta (Adj. $\mathrm{R}^{2}$ ), joka kuvaa sitä kuinka suuren osan vaihtelusta malli selitti (kokeen sisällä). Yksityiskohtaisempi kuvaus käytetystä aineistosta ja menetelmistä on esitetty Huhtasen ym. (2006) artikkelissa. 
Taulukko 1. Eri karkearehutyyppien tuhkan, raakavalkuaisen (RV), solunsisällysaineiden (NDS), kuidun (NDF), ligniinin (Lig.) ja sulamattoman kuidun (iNDF) pitoisuudet, pepsiinisellulaasiliukoisuus (OMS) ja eläimillä in vivo määritetty orgaanisen aineen (OMD), kuidun (NDFD) ja potentiaalisesti sulavan kuidun (pdNDFD) sulavuus.

\begin{tabular}{|c|c|c|c|c|c|c|c|c|c|c|}
\hline & \multicolumn{7}{|c|}{ Kuiva-aineessa (g/kg) } & \multirow{2}{*}{ OMD } & \multirow{2}{*}{ NDFD } & \multirow{2}{*}{ pdNDFD } \\
\hline & Tuhka & $\mathrm{RV}$ & NDS & NDF & iNDF & Lig. ${ }^{a}$ & OMS & & & \\
\hline \multicolumn{11}{|c|}{ Nurmiheinät 1. sadossa $(\mathrm{n}=33)$} \\
\hline Keskiarvo & 72 & 148 & 357 & 568 & 79 & 32 & 757 & 0.733 & 0.739 & 0.851 \\
\hline Keskihajonta & 8.2 & 35.0 & 67.1 & 70.1 & 39.1 & 10.5 & 70.5 & 0.0606 & 0.0701 & 0.0322 \\
\hline \multicolumn{11}{|c|}{ Nurmiheinät jälkikasvussa (n=27) } \\
\hline Keskiarvo & 94 & 144 & 376 & 533 & 106 & 28 & 757 & 0.694 & 0.701 & 0.874 \\
\hline Keskihajonta & 8.5 & 25.4 & 27.8 & 34.0 & 28.2 & 4.8 & 27.8 & 0.0339 & 0.0493 & 0.0332 \\
\hline \multicolumn{11}{|c|}{ Nurmipalkokasvit (n=19) } \\
\hline Keskiarvo & 99 & 211 & 542 & 369 & 109 & 43 & 754 & 0.707 & 0.627 & 0.893 \\
\hline Keskihajonta & 14.3 & 38.1 & 62.9 & 75.6 & 52.5 & 18.6 & 65.5 & 0.0623 & 0.0815 & 0.0441 \\
\hline \multicolumn{11}{|c|}{ Kokoviljasäilörehut (n=7) } \\
\hline Keskiarvo & 74 & 114 & 495 & 432 & 119 & 27 & 758 & 0.686 & 0.515 & 0.709 \\
\hline Keskihajonta & 10.7 & 7.2 & 71.3 & 63.2 & 30.6 & 8.1 & 69.3 & 0.0471 & 0.0300 & 0.0239 \\
\hline \multicolumn{11}{|l|}{ Kaikki $(n=86)$} \\
\hline Keskiarvo & 85 & 158 & 417 & 502 & 97 & 33 & 757 & 0.711 & 0.684 & 0.855 \\
\hline Keskihajonta & 15.6 & 43.0 & 96.1 & 100.3 & 41.2 & 12.8 & 58.0 & 0.0552 & 0.0919 & 0.0573 \\
\hline Minimi & 49 & 79 & 265 & 274 & 17 & 17 & 628 & 0.581 & 0.477 & 0.675 \\
\hline Maksimi & 122 & 301 & 627 & 669 & 211 & 79 & 878 & 0.840 & 0.869 & 0.959 \\
\hline
\end{tabular}

\section{Tulokset ja tulosten tarkastelu}

\section{Rehutyyppien väliset erot}

Tässä tarkastelussa käytetty aineisto on kuvattu taulukossa 1. Säilörehut oli vuosittain tuotettu korjaamalla samaa kasvustoa eri kehitysvaiheissa, joten rehujen koostumus ja sulavuus vaihtelivat huomattavasti. Tämä antoi hyvän lähtökohdan tarkastella eri tekijöiden ja sulavuuden välistä yhteyttä.

Rehutyyppien välillä oli selkeitä ja muun kirjallisuuden valossa (mm. Van Soest 1994) tyypillisiä eroja. Nurmiheinäsäilörehujen sadot (1. niitto vs. jälkisato) poikkesivat toisistaan siten, että 1 . sadossa kuitupitoisuus oli suurempi mutta iNDF-pitoisuus pienempi kuin 2. sadossa. Apilassa vastaavaa eroa satojen välillä ei ollut havaittavissa (tuloksia ei esitetty), mutta palkokasvirehujen kuitupitoisuus oli pienempi ja iNDF-pitoisuus suurempi kuin nurmiheinien. Kokoviljasäilörehuissa oli melko vähän kuitua, mutta kuidun sulavuus oli rehutyypeistä kaikkein huonoin.

Muita tyypillisiä rehutyyppien välisiä eroja olivat palkokasvien korkea ja kokoviljasäilörehun matala RV-pitoisuus. Tuhkapitoisuus on tyypillisesti nurmiheinien jälkikasvussa suurempi kuin 1. sadossa ja palkokasveissa vielä korkeampi. Saman OMD-tuloksen saaneista näytteistä on siis 1. sadon nurmiheinien D-arvo korkein ja palkokasvirehun matalin, koska D-arvon laskemisessa käytetään myös tuhkapitoisuutta (ks. johdanto).

Ligniinin muodostuminen ja sidosten syntyminen soluseinän polysakkariden ja ligniinin välillä ovat keskeisiä prosesseja, jotka vaikuttavat kasvien soluseinän sulavuuden laskemiseen kasvien kasvun edetessä. Ligniinipitoisuutta on käytetty kuvaamaan soluseinän laatua. Van Soest ym. (2005) esittivät, että kertomalla ligniinipitoisuus 2.4:llä voidaan arvioida sulamattoman kuidun pitoisuus. Tämän aineiston valossa näyttää kuitenkin siltä, että ligniinin ja sulamattoman kuidun yhteys vaihtelee eri rehutyypeissä (kuva 1). Toisen sadon nurmiheinissä ja kokoviljasäilörehuissa ligniini näyttää pystyvän estävän kuidun sulatusta enemmän kuin 1 . sadon nurmiheinissä ja palkokasveissa. 


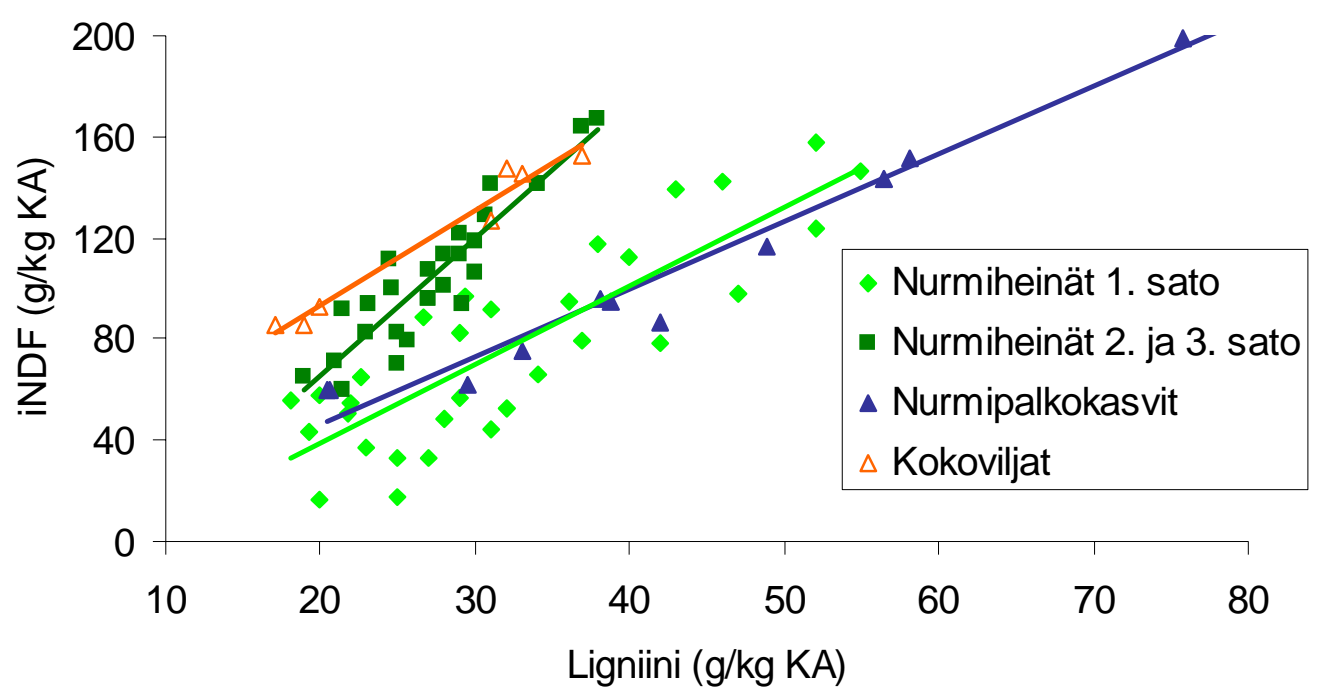

Kuva 1. Ligniinin yhteys sulamattomaan kuituun vaihteli rehutyypeittäin. Regressioyhtälöt:

$\begin{array}{lll}\text { Nurmiheinät 1. sadossa: } & \mathrm{y}=3.09 \mathrm{x}-23.1 & \left(\mathrm{R}^{2}=0.708\right) \\ \text { Nurmiheinät jälkikasvussa: } & \mathrm{y}=5.41 \mathrm{x}-43.1 & \left(\mathrm{R}^{2}=0.837\right) \\ \text { Nurmipalkokasvit: } & \mathrm{y}=2.68 \mathrm{x}-7.6 & \left(\mathrm{R}^{2}=0.970\right) \\ \text { Kokoviljat: } & \mathrm{y}=3.73 \mathrm{x}-18.7 & \left(\mathrm{R}^{2}=0.962\right) \\ \text { Kaikki: } & \mathrm{y}=2.4 \mathrm{x}+18 & \left(\mathrm{R}^{2}=0.555\right)\end{array}$

\section{Eri analyysimenetelmien empiiriset yhteydet sulavuuteen}

Taulukossa 2 on esitetty rehun koostumuksen eli raakavalkuaisen (RV) ja solunseinäkomponenttien pitoisuuksien yhteyttä sulavuuteen käyttäen koko aineistoa. Yksittäisten kemiallisten komponenttien yhteydet sulavuuteen eivät ole riittäviä sulavuuden ennustamiseen. Yksittäisen kasvuastesarjan sisällä yhteydet olivat kohtuullisia (Mixed-mallin RMSE noin 0.02 yksikköä), mutta jos tarkasteltiin koko aineistoa yksinkertaisella regressiolla, jäännösvaihtelu oli 2.5-kertainen. Yksinkertaista regressiomallia käyttäen ligniini oli "vähiten huono" (RMSE $=0.0418, \mathrm{R}^{2}=0.431$ ) ja RV-pitoisuus huonoin (RMSE = $0.0501, R^{2}=0.179$ ) sulavuuden ennustaja. Kuvassa 2 on havainnollistettu kemiallisten komponenttien eri mallien virhevaihtelua OMD:n ennustamisessa.

Kemiallisen koostumuksen yhteydet sulavuuteen voivat olla hyvin selviä otettaessa näytteitä samasta kasvustosta eri kehitysvaiheissa, kun RV-pitoisuus pienenee ja kuitupitoisuus suurenee kasvun edetessä. Yhteydet eivät kuitenkaan ole yleispäteviä eri kasvustoissa, mikä estää niiden käytön sulavuuden ennustamisessa. Raakavalkuaispitoisuuteen vaikuttaa merkittävästi kasveille käyttökelpoisen typen määrä maaperässä. Sen vaihtelut voivat aiheuttaa merkittäviä yli $10 \%$-yksikön eroja RVpitoisuudessa, vaikka kasvuston sulavuus on sama. Kuidun määrä puolestaan lisääntyy kasvun edetessä käyräviivaisesti. Varhaisissa kehitysvaiheissa kuidun määrä lisääntyy melko suoraviivaisesti kasvun edetessä, kun soluseinät paksuuntuvat. Kun soluseinät ovat saavuttaneet lopullisen kokonsa, jatkuu niiden lignifikoituminen, joten niiden sulavuus pienenee vaikka kuidun määrä ei enää lisäänny.

Taulukossa 3 on esitetty OMS:n ja taulukossa 4 iNDF:n yhteydet sulavuuteen erikseen eri rehutyypeille ja koko aineistolle yhteensä. RMSE oli noin puolet pienempi kuin kemiallisten komponenttien. OMS ja iNDF ennustivat sulavuuden suunnilleen yhtä hyvin. iNDF vaikuttaa yleispätevämmältä, sillä yksinkertaisen regression RMSE koko aineistoa käyttäen oli iNDF:a käyttäen pienempi kuin OMS:n (0.019 vs. 0.0245). Yhtälöiden kertoimet olivat jonkun verran erilaisia eri rehutyypeille, joten rehutyyppikohtaisten korjausyhtälöiden käyttäminen on perusteltua, jos rehutyyppi on tiedossa tulosta laskettaessa. Kerrointen lisäksi 1. sato ja jälkisato poikkesivat toisistaan myös muuten. Sulavuusarvot vaihtelivat huomattavasti enemmän 1 . sadossa kuin jälkisadossa (keskihajonta 0.061 vs. 0.034), mutta esimerkiksi OMS:n selitysaste oli selvästi parempi 1. sadossa jälkisatoon verrattuna (0.937 vs. 0.676). Kokoviljasäilörehunäytteitä oli käytettävissä ainoastaan 7, joten aineiston kasvattaminen olisi perusteltua yhteyksien varmentamiseksi. 
Rehutyyppikohtaiset korjausyhtälöt ovat tilasäilörehujen D-arvon määrityksen taustalla Artturirehuanalyysissä. Tässä kirjoituksessa esitettyihin yhtälöihin perustuen on myös laadittu MS Excel pohjainen tiedosto, joka on käytettävissä Artturi ${ }^{\circledR}$-verkkopalvelussa (Artturi 2007) osoitteessa https://portal.mtt.fi/portal/page/portal/Artturi/Artturikirjasto/Laskurit. Kun tiedostoon tallentaa näytteen OMS:n tai iNDF-pitoisuuden, tulokseksi saadaan OMD eri rehutyypeille.

Taulukko 2. Eri karkearehutyyppien kemiallisen koostumuksen (g/kg KA) ja orgaanisen aineen in vivo sulavuuden yhteys yksinkertaisella $(F)$ ja sekamallin $(M$, sulavuuskoe satunnaistekijänä) regressionanalyysillä.

\begin{tabular}{lcccccccc}
\hline & Malli & Vakio & s.e. $^{\text {a }}$ & $\begin{array}{l}\text { Kulma- } \\
\text { kerroin }\end{array}$ & s.e & P-arvo & RMSE $^{\text {b }}$ & Adj. ${ }^{2}$ \\
\hline Raakavalkuainen & $\mathrm{F}$ & 0.623 & 0.021 & 0.560 & 0.126 & $<0.01$ & 0.0501 & 0.179 \\
& $\mathrm{M}$ & 0.467 & 0.021 & 1.600 & 0.106 & $<0.01$ & 0.0205 & 0.918 \\
\multirow{2}{*}{ Kuitu (NDF) } & $\mathrm{F}$ & 0.811 & 0.029 & -0.200 & 0.056 & $<0.01$ & 0.0518 & 0.12 \\
& $\mathrm{M}$ & 1.096 & 0.029 & -0.760 & 0.049 & $<0.01$ & 0.0201 & 0.935 \\
Happodetergenttikuitu & $\mathrm{F}$ & 0.846 & 0.028 & -0.460 & 0.094 & $<0.01$ & 0.0489 & 0.215 \\
& $\mathrm{M}$ & 1.060 & 0.024 & -1.200 & 0.072 & $<0.01$ & 0.0192 & 0.925 \\
\multirow{2}{*}{ Ligniini } & & & & & & & & \\
& $\mathrm{F}$ & 0.805 & 0.013 & -2.860 & 0.358 & $<0.01$ & 0.0418 & 0.431 \\
& $\mathrm{M}$ & 0.846 & 0.012 & -4.190 & 0.274 & $<0.01$ & 0.0208 & 0.869 \\
\hline
\end{tabular}

${ }^{a}$ Keskivirhe (standard error)

bJäännösvaihtelu (residual mean squared error)

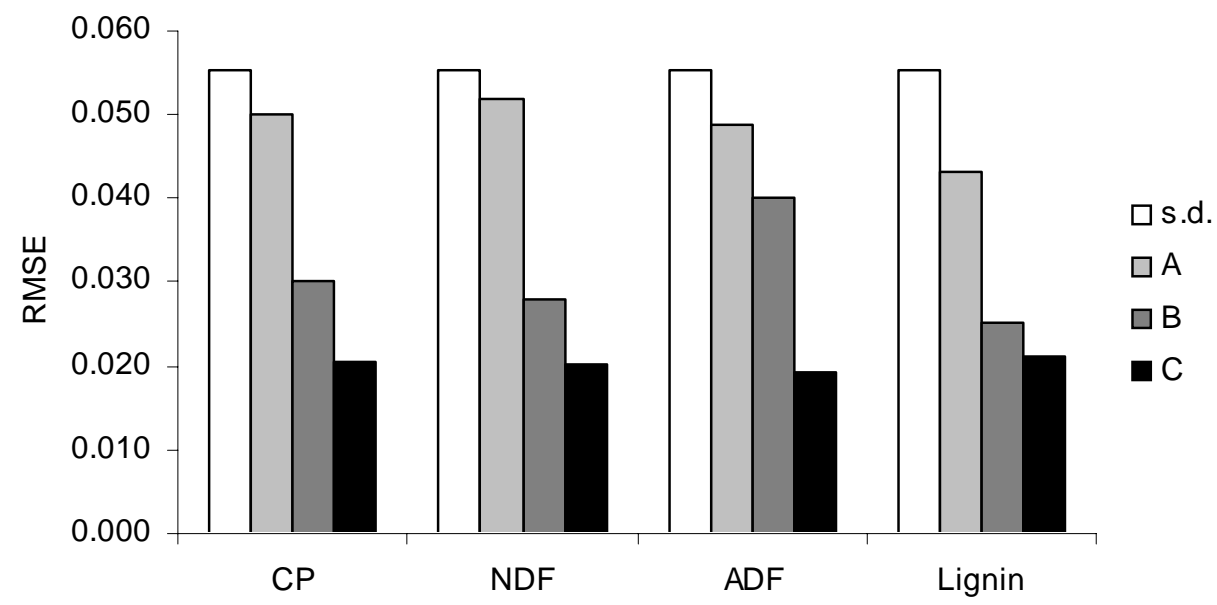

Kuva 2. Koko säilörehuaineiston raakavalkuaisen (CP), kuidun (NDF), happodetergenttikuidun (ADF) ja ligniinin keskihajonta (s.d) ja mallien jäännösvaihtelu (RMSE), kun käytettiin yksinkertaista regressiota (A), huomioitiin lisäksi rehutyyppi (B) ja tarkasteltiin yhteyksiä kokeen/kasvuastesarjan sisällä $(\mathrm{C})$. 
Taulukko 3. Eri karkearehutyyppien pepsiini-sellulaasiliukoisuuden (g/g) ja orgaanisen aineen in vivo sulavuuden yhteys yksinkertaisella (F) ja sekamallin (M, sulavuuskoe satunnaistekijänä) regressionanalyysillä.

\begin{tabular}{lcccccccc}
\hline Rehutyyppi & Malli & Vakio & s.e. $^{\text {a }}$ & P-arvo & $\begin{array}{c}\text { Kulma- } \\
\text { kerroin }\end{array}$ & s.e. & RMSE $^{\mathrm{b}}$ & Adj. $^{2}$ \\
\hline $\begin{array}{l}\text { Nurmiheinät 1. } \\
\text { sadossa }\end{array}$ & $\mathrm{F}$ & 0.103 & 0.0289 & $<0.01$ & 0.83 & 0.038 & 0.0151 & 0.937 \\
& $\mathrm{M}$ & 0.077 & 0.0211 & $<0.01$ & 0.86 & 0.027 & 0.0085 & 0.981 \\
Nurmiheinät & & & & & & & & \\
jälkikasvussa & $\mathrm{F}$ & -0.070 & 0.1030 & 0.50 & 1.01 & 0.136 & 0.0193 & 0.676 \\
& $\mathrm{M}$ & -0.154 & 0.0627 & 0.05 & 1.12 & 0.082 & 0.0091 & 0.921 \\
& & & & & & & & \\
Nurmipalko- & $\mathrm{F}$ & 0.002 & 0.0332 & 0.94 & 0.93 & 0.044 & 0.0122 & 0.962 \\
kasvit & $\mathrm{M}$ & 0.003 & 0.0332 & 0.93 & 0.93 & 0.044 & 0.0121 & 0.962 \\
& & & & & & & & \\
Kokoviljat & $\mathrm{F}$ & 0.182 & 0.0487 & 0.01 & 0.66 & 0.064 & 0.0109 & 0.947 \\
& $\mathrm{M}$ & 0.290 & 0.0996 & 0.21 & 0.52 & 0.129 & 0.0090 & 0.942 \\
Kaikki & $\mathrm{F}$ & 0.064 & 0.0348 & 0.07 & 0.86 & 0.046 & 0.0245 & 0.804 \\
& $\mathrm{M}$ & 0.040 & 0.0193 & 0.05 & 0.89 & 0.026 & 0.0099 & 0.964 \\
\hline
\end{tabular}

${ }^{\mathrm{a}}$ Keskivirhe (standard error)

bJäännösvaihtelu (residual mean squared error)

Taulukko 4. Eri karkearehutyyppien sulamattoman kuidun pitoisuuden $(\mathrm{g} / \mathrm{g})$ ja orgaanisen aineen in vivo sulavuuden yhteys yksinkertaisella (F) ja sekamallin (M, sulavuuskoe satunnaistekijänä) regressionanalyysillä.

\begin{tabular}{lcccccccc}
\hline Rehutyyppi & Malli & Vakio & s.e. $^{\mathrm{a}}$ & P-arvo & $\begin{array}{l}\text { Kulma- } \\
\text { kerroin }\end{array}$ & s.e. & RMSE $^{\mathrm{b}}$ & Adj. $^{2}$ \\
\hline $\begin{array}{l}\text { Nurmiheinät 1. } \\
\text { sadossa }\end{array}$ & $\mathrm{F}$ & 0.852 & 0.0064 & $<0.01$ & -1.52 & 0.07 & 0.0159 & 0.932 \\
& $\mathrm{M}$ & 0.851 & 0.0062 & $<0.01$ & -1.51 & 0.05 & 0.0086 & 0.979 \\
Nurmiheinät & $\mathrm{F}$ & 0.802 & 0.0137 & $<0.01$ & -1.03 & 0.13 & 0.0180 & 0.718 \\
jälkikasvussa & $\mathrm{M}$ & 0.829 & 0.0108 & $<0.01$ & -1.30 & 0.08 & 0.0072 & 0.963 \\
Nurmipalko- & $\mathrm{F}$ & 0.831 & 0.0095 & $<0.01$ & -1.14 & 0.08 & 0.0175 & 0.921 \\
kasvit & $\mathrm{M}$ & 0.832 & 0.0097 & $<0.01$ & -1.15 & 0.07 & 0.0129 & 0.956 \\
& & & & & & & & \\
Kokoviljat & $\mathrm{F}$ & 0.867 & 0.0134 & $<0.01$ & -1.52 & 0.11 & 0.0082 & 0.970 \\
& $\mathrm{M}$ & 0.867 & 0.0134 & $<0.01$ & -1.52 & 0.11 & 0.0082 & 0.970 \\
Kaikki & $\mathrm{F}$ & 0.834 & 0.0053 & $<0.01$ & -1.26 & 0.05 & 0.0190 & 0.883 \\
& $\mathrm{M}$ & 0.839 & 0.0051 & $<0.01$ & -1.32 & 0.04 & 0.0106 & 0.964 \\
\hline
\end{tabular}

${ }^{\mathrm{a}}$ Keskivirhe (standard error)

bJäännösvaihtelu (residual mean squared error)

\section{Rehun sulavuuden summatiivinen määritys}

Detergenttikuituanalyysi (Van Soest ym. 1991, Mertens 2002a) jakaa rehun liukenemattomaan kuituun (NDF, ”soluseinä”) ja neutraalidetergenttiliukoiseen aineeseen (NDS, ”solunsisällys”) eli sulatusominaisuuksien kannalta toisistaan selkeästi poikkeaviin osiin. Periaate on sama kuin Helsingin yliopiston prof. Lauri Paloheimon 1900-luvun puolivälin tienoilla kehittämässä kettoaineanalyysissä. Tämän 
periaatteen pohjalta Van Soest lähti kehittämään käytännön analytiikkaan paremmin soveltuvaa NDFanalyysiä USA:ssa (Van Soest 1999).

Solunsisällysaineiden sulavuus on lähes täydellinen ja sen vaihtelu on hyvin pientä. Kuidun sulavuus sen sijaan on selvästi vähäisempää ja vaihtelevampaa, eli rehujen sulavuuden määrityksessä oleellista on nimenomaan kuidun pitoisuuden ja sulavuuden selvittäminen.

Solunsisällysaineiden sulavuutta voidaan tarkastella Lucasin yhtälön avulla. Kun lasketaan rehuannoksen NDS:n ja sulaneen NDS:n pitoisuuksien välinen regressioyhtälö (kuva 3, taulukko 5), kuvaa kulmakerroin NDS:n todellista sulavuutta (tNDSD) ja negatiivinen vakio sonnassa erittyvän metabolisen ja endogeenisen aineksen määrää (MFOM). Koska vaihtelu on vähäistä, NDS:a voidaan pitää ns. ravitsemuksellisesti yhtenäisenä ainesosana (nutritionally uniform entity).

Tässä aineistossa havaitsimme suhteellisen pieniä, mutta mielenkiintoisia eroja rehutyyppien NDS:n todellisessa sulavuudessa ja MFOM:n määrässä. Ensimmäisestä sadosta tehtyjen nurmirehujen tNDSD oli suurempi kuin 2. sadosta tehtyjen rehujen (1.015 vs. 0.925).

Kun kuituanalyysiin yhdistetään pitkä in situ pötsi-inkubaatio, saadaan selville ns. sulamattoman kuidun pitoisuus eli se osa kuitua, joka ei missään olosuhteissa (pötsiolosuhteet ja viipymäaika eivät rajoita) tule sulatetuksi pötsissä. Näin rehun orgaaninen aine saadaan jaettua kolmeen biologisesti mielekkääseen osaan: NDS (OM-NDF), potentiaalisesti sulava kuitu (pdNDF = NDF - iNDF) ja iNDF. Koska iNDF on määritelmän mukaisesti sulamaton, sekin on ravitsemuksellisesti yhtenäinen ainesosa. Sulavuuden määrityksen kannalta huomio voidaan siis kiinnittää kuituun ja erityisesti pdNDF:n sulavuuteen. pdNDF:n vaihtelu on huomattavasti vähäisempää kuin koko kuitufraktion sulavuuden (vaihtelukerroin 4.1 vs. 11.4 \%) ja lisäksi sen osuus rehusta on pienempi (413 vs. 508 g/kg KA).

Tätä lähestymistapaa käyttäen sulavuus voidaan ennustaa ns. summatiivisella mallilla. Mallissa lasketaan näennäisesti sulanut NDS (dNDS $=$ tNDSD $\times$ NDS - MFOM), jossa tNDSD (NDS:n todellinen sulavuus) ja MFOM on määritetty Lucasin yhtälöllä (taulukko 5). Sulanut kuitu (dNDF) lasketaan kaavalla dNDF $(\mathrm{g} / \mathrm{kg} \mathrm{KA})=\mathrm{a} \times \mathrm{pdNDF}+\mathrm{b} \times \mathrm{iNDF}$, jossa a ja $\mathrm{b}$ ovat rehutyypin mukaan vaihtelevia kertoimia. Kerroin a kuvaa pdNDF:n keskimääräistä sulavuutta ja kerroin b iNDF-pitoisuuden vaikutusta pdNDF:n sulavutteen.

Kun lasketaan yhteen näennäisesti sulanut NDS ja sulanut NDF (dNDS + dNDF), tuloksena saadaan näennäisesti sulaneen orgaanisen aineen määrä eli D-arvo (kuva 4). Rehutyyppikohtaiset summatiiviset mallit ennustivat karkearehujen D-arvon lähes yhtä hyvin kuin OMS ja iNDF. Kun koko aineistoa tarkasteltiin yhdessä, summatiiviset mallit olivat parempia kuin iNDF ja erityisesti OMS (taulukko 6).

Taulukko 5. Karkearehutyyppien solunsisällysaineiden (NDS) Lucasin yhtälöt [X = rehuannoksen NDS pitoisuus (g/kg KA) ja Y = sulaneen NDS:n pitoisuus (g/kg KA)]. Negatiivinen vakio kuvaa sonnan metabolisen orgaanisen aineen määrää (g/kg KA-syönti) ja kulmakerroin solunsisällysaineiden todellista sulavuutta.

\begin{tabular}{lccccccc}
\hline Rehutyyppi & $\mathrm{n}$ & Vakio & s.e. $^{\mathrm{a}}$ & Kulmakerroin s.e. & RMSE $^{\mathrm{b}}$ & Adj. $^{2}$ \\
\hline Kaikki & 86 & -92 & 7.4 & 0.963 & 0.018 & 15.1 & 0.972 \\
Nurmiheinät 1. sadossa & 33 & -101 & 6.0 & 1.015 & 0.017 & 6.3 & 0.991 \\
Nurmiheinät jälkikasvussa & 27 & -90 & 10.2 & 0.925 & 0.027 & 4.1 & 0.978 \\
Nurmipalkokasvit & 19 & -101 & 18.0 & 0.962 & 0.034 & 10.0 & 0.979 \\
Kokoviljat & 7 & -136 & 4.0 & 1.111 & 0.008 & 1.4 & 1.000 \\
\hline
\end{tabular}

${ }^{a}$ Keskivirhe (standard error)

bJäännösvaihtelu (residual mean squared error) 


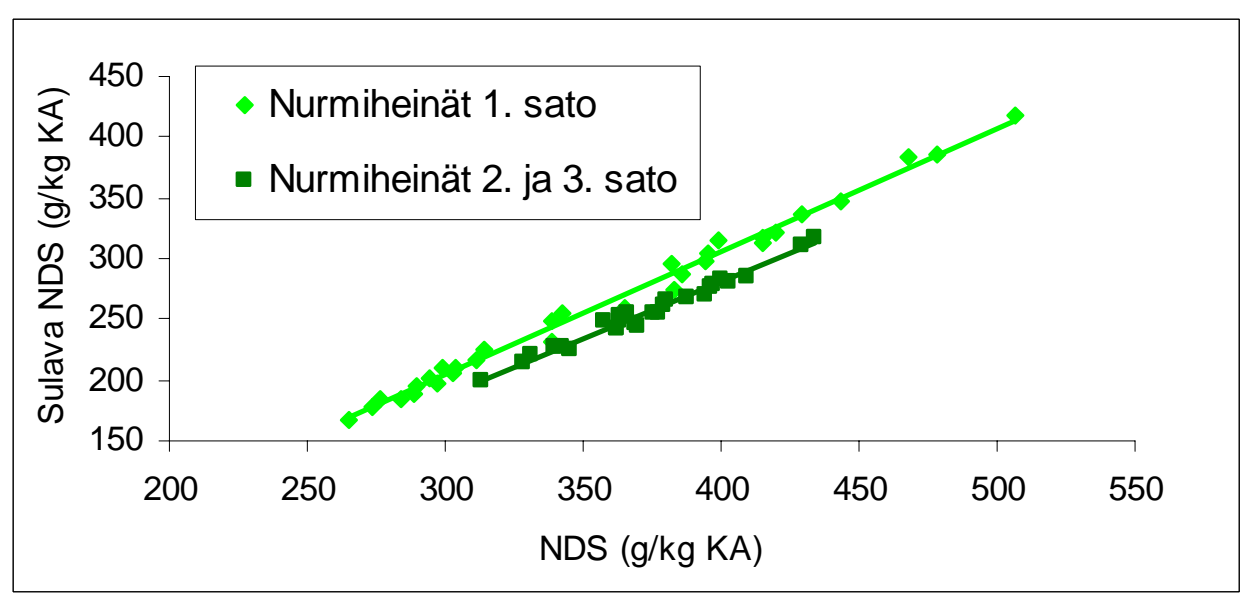

Kuva 3. Solunsisällysaineiden (NDS) Lucasin yhtälö nurmiheinäsäilörehuille, jotka on tehty 1. sadosta tai jälkikasvusta. Kaavat taulukossa 5.

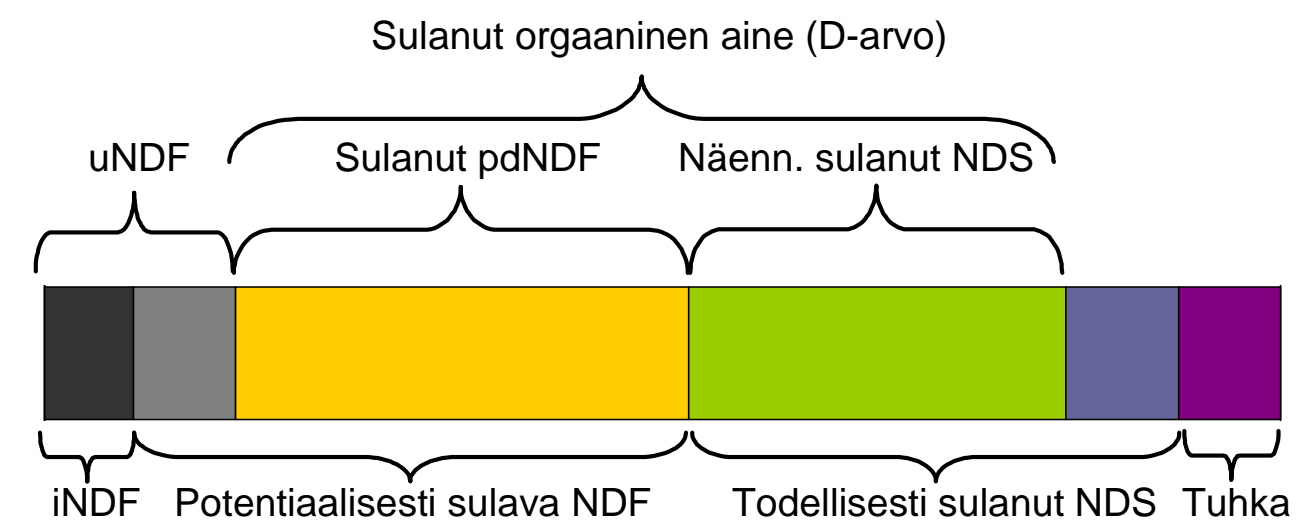

$\square$ iNDF (uNDF) $\square$ pdNDF (UNDF) $\square$ pdNDF $\square$ NDS $\square$ NDS (MFOM) $\square$ Tuhka

Kuva 4. Nurmirehun kuiva-aineen jakautuminen sulatuksen kannalta mielekkäisiin osiin eli sulamattomaan kuituun (iNDF), potentiaalisesti sulavaan kuituun (pdNDF) ja solunsisällysaineisiin (NDS). Kuvassa näkyvät lisäksi sulamaton kuitu (uNDF = iNDF + sulamatta jäänyt pdNDF) ja sonnan metabolinen orgaaninen aines (MFOM). D-arvo eli näennäisesti sulavan orgaanisen aineen pitoisuus kuivaaineessa on sulaneen kuidun ja näennäisesti sulaneiden solunsisällysaineiden summa.

Taulukko 6. D-arvon (g/kg KA) ennustaminen pepsiini-sellulaasiliukoisuudesta (OMS) tai sulamattoman kuidun (iNDF) pitoisuudesta empiirisillä malleilla tai summatiivisella Mertensin (2002b) mallilla käyttäen yleisiä (G) tai rehutyyppikohtaisia (S) yhtälöitä.

\begin{tabular}{lcccccccc}
\hline \multirow{2}{*}{ Menetelmä } & \multirow{2}{*}{ Yhtälö } & Vakio & $\begin{array}{c}\text { Kulma- } \\
\text { kerroin }\end{array}$ & \multirow{2}{*}{$\mathrm{R}^{2}$} & RMSE$^{\mathrm{b}}$ & \multicolumn{2}{c}{ MSPE: ${ }^{\mathrm{c}}$ jakautuminen } \\
\cline { 7 - 9 } & $\mathrm{G}$ & -29.2 & 1.05 & 0.816 & 22.3 & 0.000 & 0.008 & 0.992 \\
OMS & $\mathrm{S}$ & -5.1 & 1.01 & 0.929 & 13.8 & 0.000 & 0.001 & 0.999 \\
iNDF & $\mathrm{G}$ & -1.3 & 1.00 & 0.893 & 16.9 & 0.000 & 0.000 & 1.000 \\
iNDF & $\mathrm{S}$ & -49.7 & 1.08 & 0.802 & 14.3 & 0.000 & 0.000 & 1.000 \\
Mertens (2002b) & $\mathrm{G}$ & -78.3 & 1.12 & 0.912 & 16.3 & 0.001 & 0.106 & 0.893 \\
Mertens (2002b) & $\mathrm{S}$ & -13.6 & 1.02 & 0.930 & 13.7 & 0.001 & 0.005 & 0.994 \\
\hline
\end{tabular}

${ }^{\mathrm{J}}$ Jäännösvaihtelu (residual mean squared error)

${ }^{\mathrm{C}}$ Ennustevirhe (mean squared prediction error) 


\section{Rehuanalytiikka karjatilojen käyttöön}

NIRS-menetelmä (Near Infrared Reflectance Spectroscopy) on fysikaalinen mittaus, jonka avulla matemaattisia menetelmiä hyödyntäen voidaan ennustaa maatilarehujen sulavuus (katso tarkempi kuvaus mm. Nousiainen 2004, Huhtanen ym. 2006). Menetelmän etuja ovat sen edullinen hinta, nopeus ja kemiallisiin menetelmiin verrattuna hyvä toistettavuus. NIRS-menetelmä on käytössä mm. Valion Artturi-rehuanalyysissä (Artturi 2007).

NIRS-menetelmän menestyksekäs hyödyntäminen edellyttää luotettava referenssimenetelmien käyttöä, joilla voidaan tuottaa riittävän suuri aineisto luotettavan NIRS-kalibroinnin laskemiseksi. Referenssimenetelmän luotettavuudesta riippuu paljolti NIRS-sulavuusennusteiden kokonaisvirhe (Nousiainen 2004). Tässä tutkimussarjassa kehitettyjen ja validoitujen in vitro -menetelmien avulla on voitu oleellisesti lisätä NIRS-sulavuuskalibrointien tarkkuutta. Tällä hetkellä Artturi-rehuanalyysissä on käytössä tilarehujen D-arvon ennustamisessa rehutyyppikohtainen OMS:en perustuva menetelmä ja suora iNDF-kalibrointi. Jälkimmäinen kalibrointi otettiin rutiinikäyttöön ensimmäisenä maailmassa vuonna 2006. Molempien kalibrointien näytemäärät ovat niin suuria, että in vivo -menetelmiä olisi ollut mahdotonta käyttää referenssimenetelmänä.

\section{Johtopäätökset}

Yksittäisten kemiallisten komponenttien (RV, NDF, ADF, ligniini) yhteydet sulavuuteen eivät ole riittäviä sulavuuden ennustamiseen. Biologiset laboratoriomenetelmät OMS ja iNDF sen sijaan ennustivat karkearehujen orgaanisen aineen sulavuuden riittävän tarkasti käytännön ruokinnansuunnittelua varten. Ennusteiden tarkkuus parani merkittävästi, kun analyysitulokset muunnettiin sulavuudeksi rehutyyppikohtaisia korjausyhtälöitä käyttäen eli erikseen ensimmäisestä sadosta ja jälkikasvusta tehdyille nurmisäilörehuille, palkokasvisäilörehuille ja kokoviljasäilörehuille.

Jos D-arvon ennustevirhe halutaan saada pienemmäksi kuin 15 g/kg KA, on käytettävä rehutyyppikohtaisia yhtälöitä riippumatta siitä, onko laskennan perusteena OMS, iNDF tai summatiivinen malli. Toinen vaihtoehto tulevaisuudessa on mekanististen dynaamisten mallien käyttö. Ne pystyvät samanaikaisesti huomioimaan kaksi tärkeää dynaamista prosessia, jotka rajoittavat rehun sulatusta pötsissä eli kuidun virtaus- ja sulatusnopeuden. Mekanististen dynaamisten mallien käyttö edellyttää kuitenkin sitä, että rehuista voidaan helposti ja luotettavasti määrittää iNDF-pitoisuuden lisäksi kuidun sulatusnopeus. Potentiaalinen hyöty on kuitenkin varsin pieni, silla rehutyypin sisällä pdNDF:n sulavuuden vaihtelu on pientä ja/tai se korreloi iNDF-pitoisuuden kanssa. Sulatusnopeuden mittausvirheen ei tarvitse olla kovin suuri, kun sen vaikutus D-arvon ennustevirheeseen on suurempi kuin mallin paremman teorian tuoma etu. Yleisimmin kuidun sulatusnopeuden mittaamiseen käytetty in situ menetelma ei täytä tätä kriteeriä.

Tutkimuksen tuloksena käytännön tilarehujen analytiikka on merkittävästi tarkentunut, kun NIRS-kalibroinnin referenssimenetelmän luotettavuutta on pystytty parantamaan. Aikaisempi 1. sadon D-arvon aliarvostus ja jälkisadon yliarvostus on saatu poistettua. Analyysin tarkkuudessa ollaan lähestymässä lampailla tehtävien sulavuuskokeiden keskimääräistä satunnaisvirhettä, joka on teoreettinen minimivirhe, johon rehujen sulavuusmittauksissa voidaan päästä.

\section{Kirjallisuus}

Artturi, 2007. Artturi -verkkopalvelu. Viitattu 30.11.2007. Saatavilla: www.mtt.fi/artturi.

Huhtanen, P. \& Rinne, M. 2007. Effects of increasing the milk yield of dairy cows on milk composition. Journal of Animal and Feed Sciences 16, Suppl. 1, 42-58.

Huhtanen, P., Nousiainen, J., Rinne, M. 2005. Prediction of silage composition and organic matter digestibility from herbage composition and pepsin-cellulase solubility. Agricultural and Food Science 14: 154-165.

Huhtanen, P., Nousiainen, J. \& Rinne, M. 2006. Recent developments in forage evaluation with special reference to practical applications. Agricultural and Food Science 15: 293-323.

Huhtanen, P., Rinne, M. \& Nousiainen, J. 2007. Evaluation of the factors affecting silage intake of dairy cows: a revision of the relative silage dry-matter intake index. Animal 1: 758-770.

Huhtanen, P., Nousiainen, J. \& Rinne, M. 2008. Lypsylehmien rehuannoksen taloudellinen optimointi tuotosvasteiden pe-rusteella. Maataloustieteen Päivät 2008.

Kuoppala, K., Rinne, M., Nousiainen, J. \& Huhtanen, P. 2007. The effect of cutting time of grass silage in primary growth and regrowth and the interactions between silage quality and concentrate level on milk production of dairy cows. Livestock Science, in press. 
MAFF, 1984. Energy allowances and feeding systems for ruminants. Reference Book 433. Her Majesty’s Stationery Office, london, UK. 85 p.

Mertens, D.R. 2002a. Gravimetric determination of amylase-treated neutral detergent fiber in feeds with refluxing in beakers or crucibles: Collaborative study. Journal of AOAC International 85: 1217-1240.

Mertens, D.R. 2002b. Fiber: measuring, modelling and feeding. In: Proceedings Cornell Nutrition Conference for Feed Manufacturers. 23-25 Oct 2002. East Syracuse, NY. p. 1-18.

MTT, 2006. Rehutaulukot ja ruokintasuoistukset -verkkopalvelu. Saatavilla: www.agronet.fi/rehutaulukot.

Nousiainen J. 2004 Development of tools for the nutritional management of dairy cows on silage-based diets. Ph.D. thesis, Department of Animal Science Publication 72, University of Helsinki, Finland. http://ethisis.helisinki.fi/julkaisut/maa/kotie/vk/nousiainen/

Nousiainen, J., Rinne, M., Hellämäki, M. \& Huhtanen, P. 2003. Prediction of the digestibility of the primary growth of grass silages harvested at different stages of maturity from chemical composition and pepsin-cellulose solubility. Animal Feed Science and Technology, 103: 97-111.

Rinne, M., Olt, A., Nousiainen, J. Seppälä, A., Tuori, M., Paul, C., Fraser, M.D. \& Huhtanen, P. 2006. Prediction of legume silage digestibility from various laboratory methods. Grass and Forage Science 61:354-362 Rinne, M. 2000. Influence of the timing of the harvest of primary grass growth on herbage quality and subsequent digestion and performance in the ruminant animal. University of Helsinki, Department of Animal Science. Publications 54. 42 p. + 5 encl. Available at: http://ethesis.helsinki.fi/julkaisut/maa/kotie/vk/rinne.

Rinne, M. \& Huhtanen, P. 2006. Paljonko maitoa saa tonnista rehuviljaa? ProAgria Maito -valmennus, Vantaa 24.8.2006. Saatavilla: https:/portal.mtt.fi/portal/page/portal/Artturi/Artturikirjasto/Artturikoulutus/ProAgria\% 20Maito\%20-valmennus\%202006\%20\%20Koulutusmateriaali/Marketta\%20Rinne\%202006.pdf

Rinne, M., Jaakkola, S., Kaustell, K., Heikkilä, T. \& Huhtanen, P. 1999. Silages harvested at different stages of grass growth versus concentrate foods as energy and protein sources in milk production. Animal Science 69: 251-263.

Rinne, M., Huhtanen P. \& Nousiainen, J. 2008. Säilörehun ja koko rehuannoksen syönti-indeksit auttavat lypsylehmien ruokinnan suunnittelussa. Maataloustieteen Päivät 2008.

Stefanska, J., Rinne, M., Heikkilä, T. \& Ahvenjärvi, S. 2008. In vivo digestibility of different types of forage using sheep as the model of ruminants. Maataloustieteen Päivät 2008.

Tilley, J. \& Terry, R. 1963. A two-stage technique for the in vitro digestion of forage crops. Journal of the British Grassland Society 18, 104-111.

Van Soest, P.J. 1994. Nutritional ecology of the ruminant. Second Edition. Comstock Publishing Associates, Cornell University Press, Ithaca and London. 476 p.

Van Soest, P.J. 1999. Prof. Lauri Paloheimo, pioneer in ruminant nutrition. Professori Lauri Paloheimon 100vuotisjuhlaseminaari 16.11.1999, Helsinki. Suomen Nurmiyhdistyksen julkaisu nro 12: 9-25.

Van Soest, P.J., Robertson, J. B., \& Levis, B.A. 1991. Methods for dietary fibre neutral detergent fibre and nonstarch polysaccharides in relation to animal nutrition. Journal of Dairy Science 74: 3583-3597

Van Soest, P.J., Van Amburgh, M.E., Robertson, J.B. \& Knaus W.F. 2005. Validation of the 2.4 times lignin factor for ultimate extent of NDF digestion, and curve peeling rate of fermentation curves into pools. In: Proceedings Cornell Nutrition Conference for Feed Manufacturers. 24-26 Oct 2005. East Syracuse, NY. p. 139149. 